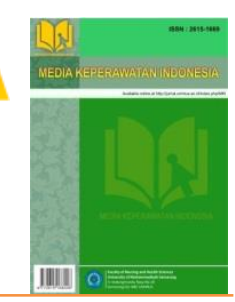

\title{
The Effect of Benson Relaxation Technique on a Scale Of Postoperative Pain in Patients with Benign Prostat Hyperplasia at RSUD dr. H Soewondo Kendal
}

\author{
Arifianto' $^{1}$ Dwi Nur Aini², Novita Diana Wulan Sari ${ }^{3}$ \\ 1,2,3 Health Science Institute of Widya Husada Semarang
}

\begin{tabular}{|c|c|c|}
\hline Article Info & & Abstract \\
\hline $\begin{array}{l}\text { Article History: } \\
\text { Accepted February } \\
2019 \\
\text { Key words: } \\
\text { Benson Relaxation } \\
\text { Technique; } \\
\text { Pain Scale }\end{array}$ & $13 \mathrm{rd}$ & $\begin{array}{l}\text { Background : Benign Prostate Hyperplasia (BPH) is a disease enlargement } \\
\text { or hypertrophy of the prostate. Each surgery will arise as a result of wound } \\
\text { incision procedures. Based on pre-study post operative patients with } \\
\text { benign prostate hyperplasia in Dr.H Soeowndo Kendal General Hospital } 4 \\
\text { out of } 5 \text { patients said that after surgery they experienced pain around the } \\
\text { post operative.These wounds will stimulate the pain response Handling of } \\
\text { non-pharmacological that can be done is by Benson relaxation therapy. The } \\
\text { objective of this research there is an effect of Benson relaxation technique } \\
\text { on a scale of postoperative pain in patients with Benign Prostate } \\
\text { Hyperplasia at RSUD dr. H Soewondo Kendal. Methods : Design Research } \\
\text { use quasi experiment. designs with pre and post-test without a control } \\
\text { sample with } 32 \text { people. Relaxation Benson techniques are done taxable } \\
\text { income provision with analgesic duration of } 8 \text { hours. And after before } \\
\text { given relaxation techniques Benson carried measurement scale with a } \\
\text { numeric pain rating scale. Result : Results of Statistics Wilcoxon Sign } \\
\text { Rank test with confidence level of } 95 \% \text { ( } \alpha=0.05) \text { and obtained p value } \\
0.000<0.05 \text {. Conclusion : the result of this research there is an effect of } \\
\text { benson relaxation technique on a scale of postoperative pain in patients } \\
\text { with Benign Prostat Hyperplasia at RSUD dr. H Soewondo Kendal. }\end{array}$ \\
\hline
\end{tabular}

\section{PENDAHULUAN}

Benigna Prostat Hiperplasia (BPH) merupakan suatu penyakit dimana terjadi pembesaran dari kelenjar prostat akibat hiperplasia jinak dari sel-sel yang biasa terjadi pada laki-laki berusia lanjut (Bufa, 2006 dalam Samidah \& Romadhon, 2015). Kondisi patologis ini paling sering terjadi pada pria lansia dan penyebab kedua yang paling sering ditemukan untuk intervensi medis pada pria di atas usia 50 tahun. (Wijaya \& Putra, 2013). Di dunia, hampir 30 juta pria menderita BPH pada usia 40 tahun sekitar 40\%, usia 60-70 tahun meningkat menjadi $50 \%$ dan usia lebih dari 70 tahun mencapai 90\%. Diperkirakan sebanyak $60 \%$ pria usia lebih dari 80 tahun memberikan gejala Lower Urinary Tract sympstons (LUTS). Di Amerika Serikat, hampir 14 juta pria menderita BPH. Prevalensi dan kejadian BPH di Amerika Serikat terus meningkat pada tahun 19942000 dan tahun 1998-2007. Peningkatan jumlah insiden ini akan terus berlangsung sampai beberapa dekade mendatang (Sampekalo, Manoarfa, \& Salem, 2015). Angka kejadian BPH di Jawa Tengah secara

Corresponding author:

Arifianto

arif.dok82@gmail.com

Media Keperawatan Indonesia, Vol 2 No 1, February 2019

e-ISSN: 2615-1669

DOI:10.26714/mki.2.1.2019.1-9 
mikroskopi dan anatomi sebesar $40 \%$ dan 90\% terjadi pada rentang usia 50-60 tahun dan 80-90 tahun (Amalia , 2010). Penatalaksanaan jangka panjang pada pasien dengan BPH adalah dengan melakukan pembedahan. Salah satu tindakan yang paling banyak dilakukan pada pasien dengan $\mathrm{BPH}$ adalah tindakan pembedahan Transurethral Resection of the Prostate (TURP) yang prosedur pembedahan dengan memasukkan resektoskopi melalui uretra untuk mengeksisi dan mengkauterisasi atau mereseksi kelenjar prostat yang mengalami obstruksi. Prosedur tersebut menimbulkan luka bedah yang berakibat menimbulkan nyeri pada luka post operasi. (Purnomo, 2011)

Penatalaksanaan nyeri non farmakologi merupakan terapi pelengkap untuk mengurangi nyeri pasca bedah dan bukan sebagai pengganti utama terapi analgetik yang telah diberikan (Anonimous 2007 dalam Datak, Yetti, \& Hariyati, 2008) Penatalaksanaan nonfarmakologi mencakup terapi agen fisik dan intervensi perilaku kognitif. Salah satu intervensi perilaku kognitif yang digunakan untuk mengurangi nyeri pasca operasi adalah relaksasi Benson. Relaksasi Benson merupakan gabungan antara teknik respon relaksasi dan sistem keyakinan individu/ faith factor difokuskan pada ungkapan tertentu berupa nama-nama Tuhan atau kata yang memiliki makna menenangkan bagi pasien itu sendiri yang diucapkan berulang-ulang dengan ritme teratur. Keyakinan memiliki pengaruh fisik atau bahkan jiwa manusia yaitu relevan serta berpengaruh dalam terapi dan pencegahan penyakit. (Benson \& Proctor 2000 dalam Solehati, \& Kosasih, 2015).

Berdasarkan studi pendahuluan pada tanggal 18 Maret 2018 di ruang Kenanga RSUD dr. H Soewondo Kendal didapatkan data pasien bedah dengan kategori Prostatektomy mengalami peningkatan setiap tahunnya. Pada tahun 2015 terdapat 103 pasien post operasi BPH, tahun 2016 terdapat 132 pasien post operasi BPH dan pada tahun 2017 mengalami peningkatan menjadi 156 pasien post operasi BPH, sedangkan data ditahun 2018 dari bulan Januari sampai Maret 2018 terdapat 47 pasien yang menjalani post operasi BPH. Masalah keperawatan utama yang muncul pada pasien dengan post operasi $\mathrm{BPH}$ adalah nyeri akut.

Berdasarkan hasil wawancara 5 dari 7 perawat mengatakan bahwa belum pernah dilakukan terapi non farmakologi berupa terapi relaksasi Benson untuk menurunkan skala nyeri, pasien yang mengalami nyeri post operasi hanya diberikan terapi relaksasi nafas dalam saja dan belum begitu efektif untuk menurukan skala nyeri. Dari hasil wawancara 4 dari 5 pasien setelah operasi prostatectomy di peroleh informasi bahwa setelah pembedahan pasien mengatakan mengalami nyeri di sekitar luka post operasi. Selama perawatan pasien mendapatkan tindakan perawatan luka dan bila rasa nyeri kambuh perawat memberikan obat yang mampu meringankan rasa nyeri.

\section{METODOLOGI PENELITIAN}

Penelitian ini menggunakan rancangan eksperimen semu (quasy experiment) dengan desain pre and post test without control. Populasi dalam penelitian ini adalah pasien post operasi BPH sebanyak 32 pasien di Ruang Kenanga RSUD dr. H Soewondo Kendal pada bulan Juni sampai Agustus 2018 yang diambil dengan menggunakan teknik purposive sampling dengan menggunakan Uji Non Parametrik Wilcoxon Match Pair Test karena sakala data ordinal.

Instrumen dalam penelitian menggunakan koesioner, Lembar observasi skala nyeri dengan menggunakan Numeric Rating Scale, Stopwatch, dan Teknik terapi relaksasi Benson. 
Etika penelitian meliputi Informent consen, Anonimity, Beneficiency, Justice, dan Confidentiality.

\section{HASIL PENELITIAN}

\section{Karakteristik Responden}

Tabel 1

\section{Karakteristik Responden, $\mathrm{n}=32$}

\begin{tabular}{lcc}
\hline \multicolumn{1}{c}{ Indikator } & f & \% \\
\hline Umur & & \\
a. 40-60 tahun & 11 & 34,4 \\
b. $>60$ tahun & 21 & 65,6 \\
\hline Pendidikan & & \\
a. SD & 17 & 53,1 \\
b. SMP & 7 & 21,9 \\
c. SMA & 5 & 15,6 \\
d. Sarjana & 3 & 9,4 \\
\hline Pekerjaan & & \\
a. PNS & 3 & 9,4 \\
b. Swasta & 5 & 15,6 \\
c. Petani & 13 & 40,6 \\
d. Nelayan & 2 & 6,3 \\
e. Tidak bekerja & 9 & 28,1 \\
\hline Nyeri Sebelum & & \\
Intervensi & & \\
a. Nyeri ringan & 3 & 9,4 \\
b. Nyeri sedang & 29 & 90,6 \\
\hline Nyeri Setelah & & \\
Intervensi & & \\
a. Nyeri ringan & 23 & 71,9 \\
b. Nyeri sedang & 9 & 28,1 \\
\hline
\end{tabular}

Berdasarkan tabel 1 diketahui bahwa sebagian besar responden berusia $>60$ tahun sebanyak 21 responden $(65,6 \%)$. Pendidikan responden sebagian besar berpendidikan SD sebanyak 17 responden (53,1\%). Pekerjaan responden sebagian besar bekerja sebagai petani sebanyak 13 orang $(40,6 \%)$. Sebagian besar responden mengalami nyeri sedang sebanyak 29 responden $(90,6 \%)$ sebelum pemberian terapi relaksasi benson. Sebagian besar responden mengalami nyeri ringan sebangak 23 responden (71,9\%) setelah diberikan terapi relaksasi benson.

\section{Pengaruh Terapi Relaksasi Benson Terhadap Nyeri}

Tabel 2

Pengaruh Terapi Relaksasi Benson Terhadap Nyeri, $\mathrm{n}=32$

\begin{tabular}{cccc}
\hline $\begin{array}{c}\text { Tingkat } \\
\text { nyeri }\end{array}$ & Frekuensi & $\mathbf{Z}_{\text {hitung }}$ & $\begin{array}{c}\boldsymbol{P} \text { - } \\
\text { Value }\end{array}$ \\
\hline Negatif ranks & 27 & $-4,618$ & 0,000 \\
Positif rank & 0 & & \\
Ties & 5 & & \\
\hline Total & 32 & & \\
\hline
\end{tabular}

Responden yang mengalami penurunan skala nyeri setelah diberikan terapi relaksasi Benson sebanyak 27 responden, yang tidak mengalami perubahan skala nyeri setelah diberikan terapi relaksasi benson sebanyak 5 responden dan tidak ada responden yang mengalami peningkatan skala nyeri setelah diberikan terapi relaksasi benson. Hasil uji wilcoxon didapatkan hasil $p$ value $0,00<0,05$ maka $\mathrm{H}_{0}$ ditolak dan $\mathrm{H}_{a}$ diterima dengan demikian dikatakan ada pengaruh terapi relaksasi benson terhadap skala nyeri pada pasien post operasi Benigna Prostat Hiperplasia di ruang Kenanga RSUD Dr. H Soewondo Kendal.

\section{PEMBAHASAN}

Hasil penelitian tentang umur responden diketahui 21 orang $(65,6 \%)$ berusia $>60$ tahun. Menurut Purnomo, 2011 terdapat perubahan mikroskopik pada prostat lakilaki yang berusia 30-40 tahun, bila perubahan mikroskopik ini berkembang maka akan terjadi perubahan patologik anatomi yang terjadi pada laki-laki yang berusia 60 tahun, dan angka kejadiannya sekitar 50\% untuk usia > 60 tahun. Umur sangat erat kaitannya dengan proses penuaan, penambahan usia akan meningkatkan perubahan keseimbangan testosteron, kelemahan pada buli (otot detrusor) dan penurunan fungsi persarafan. Perubahan karena pengaruh umur yang sudah tua menurunkan kemampuan bulibuli dalam mempertahankan aliran urin 
pada proses adaptasi oleh adanya obstruksi karena pembesaran Benigna Prostat Hiperplasia sehingga menimbulkan gejala. Sesuai dengan bertambahnya umur, kadar testoteron mulai menurun secara perlahan pada usia 30 tahun keatas dan turun lebih cepat pada usia 60 tahun keatas (Nursalam \& Batticaca, 2009). Hasil penelitian ini sejalan dengan penelitian yang dilakukan oleh Setyawan, Saleh, \& Arfan, 2016 yang menjelaskan bahawa kejadian Benigna Prostat Hiperplasia di RSUD Dr. Soedarso Pontianak sebanyak $68,2 \%$ orang berusia 60-74 tahun.

Tingkat pendidikan responden sebagian besar berpendidikan SD sebanyak 17 orang (53,1\%). Tingkat pendidikan merupakan salah satu faktor predisposisi terbentuknnya tingkat pengetahuan. Notoatmodjo, 2012 menjelaskan bahwa tingkat pendidikan seseorang berpengaruh pada tingkat pengetahuan, sikap dan perilaku, termasuk berperilaku hidup sehat. Pendidikan responden yang banyak pada sekolah dasar dapat mempengaruhi pengetahuan dan perilaku dalam pencegahan Benigna Prostat Hiperplasia, seperti mengurangi ataupun berhenti mengkonsumsi kafein dan membiasakan tidak minum apapun 2 jam sebelum tidur supaya terhindar dari nocturia ataupun berkemih sepanjang malam. Hasil ini sejalan dengan hasil penelitian yang dilakukan oleh Sukesih \& Ros, 2017 menjelaskan bahwa $80 \%$ responden yang mengalami Prostat Benigna Hiperplasia Di Ruang Bougenfile dan Mawar RSUD RAA Soewondo Pati berpendidikan tidak tamat SD - SD.

Berdasarkan hasil penelitian diketahui 13 orang $(40,6 \%)$ bekerja sebagai petani. Pekerjaan seseorang umumnnya memiliki dampak yang penting dalam upaya meminimalisasi seseorang dalam terkena penyakit Benigna Prostat Hiperplasia. Pekerjaan petani identik dengan pekerjaan yang cukup berat dibandingkan dengan pekerjaan lainnya. Pekerjaan tersebut umumnnya menguras keringat karena lebih banyak menggunakan otot dibandingkan dengan pikiran. Fenomena di Indonesia petani menghabiskan waktu setiap harinnya di sawah dengan mencangkul, membajak sawah, mengangkat beban berat, pekerjaan seperti ini dilakukan secara terus menerus oleh petani sebagai rutinitas.

Petani juga sering memiliki kebiasaan yang buruk yaitu sering menahan kencing saat bekerja akibatnnya terjadi Obstruksi urin yang akan berkembang secara perlahanlahan sehingga mengakibatkan aliran urin tidak deras dan sesudah berkemih masih ada urin yang menetes, Gejala iritasi ini menyertai obstruksi urin dimana vesika urinaria akan mengalami iritasi dari urin yang tertahan didalamnya sehingga seseorang merasa bahwa vesika urinarianya tidak menjadi kosong. Proses pembesaran prostat akan terjadi secara perlahan-lahan sehingga perubahan pada saluran kemih juga terjadi secara perlahanlahan. Pada tahap awal setelah terjadi pembesaran prostat resistensi pada leher buli-buli dan daerah prostat meningkat, serta otot destrusor menebal dan merenggang sehingga timbul sakulasi atau divertikel. (Purnomo, 2011).

Hasil penelitian ini juga sejalan dengan Wulandari \& Asnindari, 2018 menjelaskan bahwa 73,3 \% responden yang mengalami Benigna Prostat Hiperplasia di RSU PKU Muhammadyah Bantul memiliki pekerjaan sebagai petani. Tingginnya angka kejadian BPH pada petani sering dikaitkan dengan usia. Hampir semua petani adalah berusia > 60 tahun dimana semakin tinggi usia juga semakin tinggi kejadian $\mathrm{BPH}$.

Hasil penelitian karakteristik status perkawinan diketahui $75 \%$, telah menikah. Adanya hubungan Aktivitas seksual dan Hipertropi Prostat bisa saja terjadi, ini dikarenakan responden yang diteliti hampir semuanya telah menikah, seseorang yang telah menikah melakukan aktivitas seksual yang dilakukan lebih dibandingkan yang belum menikah sehingga resiko untuk 
terkena Hipertropi Prostat akan lebih besar dibandingkan yang belum menikah.

Penelitian ini sejalan dengan yang dilakukan oleh Setyawan, Saleh, \& Arfan, 2016 memperlihatkan bahwa ada hubungan antara aktivitas seksual dengan kejadian Benigna Prostat Hiperplasia yang beresiko ialah dengan melakukan aktivitas sekual dengan ejakulasi yang sering.

\section{Skala Nyeri Pasien post Operasi Benigna Prostat Hiperplasia sebelum Diberi Terapi Relaksasi Benson Pada Pasien Post Operasi Benigna Prostat Hiperplasia di Ruang Kenanga RSUD Dr. H Soewondo Kendal}

Berdasarkan hasil penelitian pada 32 responden post operasi benigna prostat hiperplasia sebelum diberi terapi relaksasi benson diketahui 29 responden $(90,6 \%)$ mengalami nyeri skala sedang sedangkan 3 responden $(9,4 \%)$ mengalami nyeri ringan. Benigna Prostat Hiperplasia (BPH) adalah suatu penyakit pembesaran atau hipertrofi dari prostat. Hiperplasia merupakan pembesaran ukuran sel (kualitas) dan diikuti oleh penambahan jumlah sel (kuantitas). BPH seringkali menyebabkan gangguan dalam eliminasi urine karena pembesaran prostat yang cenderung kearah depan atau menekan vesika urinaria (Pranata \& Prabowo, 2014).

Menurut Potter \& Perry (2009) setiap tindakan pembedahan akan timbul masalah infeksi luka akibat prosedur insisi. Luka ini akan merangsang terjadinya respon nyeri. Nyeri merupakan perasaan yang tidak menyenangkan bagi sebagian orang. Nyeri sering kali dikaitkan dengan kerusakan pada tubuh yang merupakan peringatan terhadapadanya ancaman yang bersifat aktual atau potensial. Menurut Kneale \& Peter, (2011) Tindakan pembedahan tersebut menyebabkan rasa nyeri sehingga dapat menimbulkan komplikasi yang serius dan menghambat proses pemulihan pasien jika tidak dilakukan manajemen nyeri dengan baik. Pasien yang dilakukan tindakan operasi mengalami nyeri akut setelah operasi sekitar $80 \%$.

Menurut hasil penelitian pada intensitas nyeri responden sebelum diberi Terapi Relaksasi Benson diketahui sebagaian besar responden mengalami nyeri pada skala sedang, hal ini karena setelah dilakukan pembedahan dimana terjadi iritasi mukosa kandung kemih atau terputusnnya jaringan sehingga merangsang saraf diameter kecil menuju aferen yang mengakibatnya nyeri tersebut timbul. Hasil penelitian ini juga sejalan dengan penelitian Wulandari \& Asnindari, (2018) diketahui bahwa intensitas nyeri post operasi TURP pada pasien BPH di RS Muhammadiyah Bantul mengalami nyeri ringan skala $3(40 \%)$ dan nyeri Sedang Sakala 5 (33,3\%). Penelitian juga sejalan dengan penelitian Fitria \& Ambarwati, (2015) dengan judul Efektifitas Teknik Relaksasi Progresif Terhadap Intensitas Nyeri Pasca Operasi Laparatomi di ruang Mawar II RSUD Dr. Moewardi Solo diketahui bahwa rata-rata mengalami nyeri dengan kategori nyeri sedang sebelum diberikan intervensi adalah 5.93

Salah satu cara untuk menurunkan skala nyeri post operasi BPH yaitu memberikan terapi relaksasi benson kepada pasien dimana terapi benson merupakan terapi dengan cara non farmakologi dalam pain management dan merupakan tindakan yang dapat dilakukan perawat untuk menyelesaikan permasalahan biologis pasien.

\section{Skala Nyeri Pasien post Operasi Benigna Prostat Hiperplasia setelah Diberi Terapi Relaksasi Benson Pada Pasien Post Operasi Benigna Prostat Hyperplasia di Ruang Kenanga RSUD dr. H Soewondo Kendal}

Hasil penelitian skala nyeri pada responden setelah diberi terapi relaksasi benson diketahui 23 responden $(71,9$ \%) mengalami nyeri skala ringan. Adanya penurunan skala nyeri pada responden terjadi setelah diberikan terapi relaksasi 
Benson selama 15 menit. Relaksasi benson merupakan relaksasi yang menggabungkan antara teknik respons relaksasi dan system keyakinan individu atau faith factor (difokuskan pada ungkapan tertentu berupa nama-nama Tuhan, atau kata yang memiliki makna menenangkan bagi pasien itu sendiri) yang diucapkan berulang-mulang dengan ritme teratur disertai sikap pasrah. Relaksasi bertujuan untuk mengatasi atau mengurangi kecemasan, menurunkan ketegangan otot dan tulang, serta secara tidak langsung dapat mengurangi nyeri dan menurunkan ketegangan yang berhubungan dengan fisiologi tubuh. Pelatihan relaksasi bertujuan untuk melatih pasien agar dapat mengkondisikan dirinya untuk mencapai suatu keadaan rileks.

Pemberian terapi benson kepada responden yang seluruhnya beragama Islam, maka terapi benson diberikan dengan cara membimbing responden untuk berdoa seperti biasa dilakukan seperti menyebut nama Allah. Terapi benson ini dengan mengucapkan Subhanallah (Maha suci Allah), Alhamdullilah (segala puji bagi Allah), Allahuakbar (Allah Maha Besar), Lailaha-illallah (Tiada Tuhan selain Allah ) dengan nada suara rendah dan berulang ulang dalam waktu 15 menit. Pada proses meditasi terapi benson ini konsentrasi pikiran dilakukan pada Allah secara terus menerus, tanpa henti dan secara sadar serta dilakukan dengan totalitas baik kognitif atau emosional terhadap Allah SWT. Terapi benson yang dilakukan pasien sebagai bentuk relaksasi untuk mencegah stimulus nyeri masuk kedalam otak sangat bermanfaat untuk membantu pasien mengontrol nyeri pasca operasi $\mathrm{BPH}$.

Konsep dari Herbert Benson apabila melakukan relaksasi selama 15 menit akan menyebabkan aktivitas saraf simpatik dihambat sedangkan saat pasien relaksasi yang akan bekerja sistem saraf parasimpatis yang akan mengakibatkan penurunan terhadap konsumsi oksigen oleh tubuh selanjutnnya otot - otot tubuh menjadi relaks sehingga menimbulkan perasaan tenang dan nyaman dengan demikian relaksasi dapat menekan rasa nyeri (Sunaryo \& Lestari, 2015).

\section{Pengaruh Terapi Relaksasi Benson Terhadap Skala Nyeri Pada Pasien Post Operasi Benigna Prostat Hiperplasia}

Hasil penelitian diperoleh nilai $p$ value sebesar $0,000<0,05$ yang berarti $\mathrm{H}_{0}$ ditolak sedangkan $\mathrm{H}_{\mathrm{a}}$ diterima, sehingga disimpulkan Ada pengaruh terapi relaksasi Benson terhadap skala nyeri pada pasien post operasi Benigna Prostat Hiperplasia.

Hasil penelitian juga diketahui bahwa responden mengalami penurunan skala nyeri setalah diberikan terapi relaksasi benson yaitu rata-rata nyeri responden sebelum diberikan terapi sebesar 5,00 dan setelah diberikan terapi relaksasi benson rata-rata nyeri menurun menjadi 3,06 . Hal ini sesuai dengan Solehati, \& Kosasih, (2015) menyatakan bahwa salah satu manfaat dari terapi relaksasi benson adalah menurunkan nyeri. Bagi penderita yang sangat membutuhkan teknik menurunkan skala nyeri, terapi relaksasi benson terbukti bekerja dengan cara menghambat saraf simpatik dan mengakibatkan saraf parasimpatik bekerja akibatnnya otot-otot tubuh menjadi rileks dan menekan rasa nyeri pada pasien.

Hasil penelitian juga diketahui bahwa responden yang mengalami penurunan skala nyeri setelah diberikan terapi relaksasi benson sebanyak 27 responden, tidak ada peningkatan nyeri setelah diberikan terapi relaksasi, sebelum dan setelah pemberian terapi relaksasi benson tidak terjadi perubahan pada skala nyeri sebanyak 5 responden.

Tidak adanya penurunan skala nyeri dari 5 responden tersebut setelah melakukan terapi Benson dapat dipengaruhi oleh beberapa faktor seperti, rasa kurang percaya diri pada diri responden dan faktor lingkungan. Hal ini karena pada saat dilakukan terapi benson, kondisi 
lingkungan diruang Kenanga kurang kondusif karena pada saat peneliti membimbing responden melakukan relaksasi keluarga responden yang sedang tidak diteliti sedang bercakap-cakap dengan pasien lain, sehingga fokus responden yang diteliti menjadi terganggu serta ada responden yang tidak ditemani oleh anggota keluarga. Ketidak hadiran anggota keluarga menjadikan responden menjadi cemas, sehingga pelaksanaan terapi benson dengan melakukan dzikir menjadi kurang fokus. Hal inilah yang menyebabkan pada hasil penilaian skala nyeri post operasi kepada 5 responden tidak mengalami perubahan atau tetap.

Faktor yang diperkirakan oleh peneliti adanya penurunan skala nyeri setelah diberikan terapi relaksasi Benson adalah sebagaian besar responden adalah berusia diatatas 60 tahun (lanjut usia), sehingga responden memiliki kematangan spiritual yang baik sehingga memudahkan pelaksananaan Relaksasi Benson dengan berikhtiar menyebut nama Allah. Menurut Potter \& Perry, (2009) setiap tindakan pembedahan akan timbul masalah nyeri akibat prosedur insisi. Luka ini akan merangsang terjadinya respon nyeri. Nyeri merupakan perasaan yang tidak menyenangkan bagi sebagian orang. Nyeri sering kali dikaitkan dengan kerusakan pada tubuh yang merupakan peringatan terhadap adanya ancaman yang bersifat aktual atau potensial. Menurut Kneale \& Peter, (2011) tindakan pembedahan tersebut menyebabkan rasa nyeri sehingga dapat menimbulkan komplikasi yang serius dan menghambat proses pemulihan pasien jika tidak dilakukan manajemen nyeri dengan baik. Pasien yang dilakukan tindakan operasi mengalami nyeri akut setelah operasi sekitar $80 \%$. Hasil penelitian ini memperkuat penelitian Rasubala , Kumaat , \& Mulyadi (2017), yang menjelaskan terdapat pengaruh yang signifikan pada teknik relaksasi Benson terhadap skala nyeri pada pasien post operasi apendiksitis di RSUP. Prof. Dr. R.D.
Kandou Manado dan RS TK. III R.W. Mongosidi Telling Manado.

Relaksasi benson dikembangkan dari metode respon relaksasi dengan melibatkan faktor keyakinan (faith factor). Pasien melakukan relaksasi dengan mengulang kata atau kalimat yang sesuai dengan keyakinan responden sehingga menghambat impuls noxius pada sistem kontrol desending (gate control theory) dan meningkatkan kontrol terhadap nyeri. Responden yang semuanya beragama Islam malakukan terapi relaksasi Benson ini diwujudkan dengan melafalkan nama-nama Allah sebagai dari rangkaian doa yang mempunyai makna sebagai pengakuaan atas kebesaran Allah SWT. Pengakuan sacara khafah seperti subbhanallah bahwa memang benar Allah yang mempunyai sifat maha suci, mengucapkan alhamdullilah, bahwa hanya Allah yan patut untuk dipuji, Allahu akbar yaitu bahwa Allah Maha Besar atas segala ciptaanNya dan bacaan Lailaha-illallah (Tiada Tuhan selain Allah) yang mampu memberikan pertolongan kepada makhlukNya. Oleh karena itu dengan pengucapan terapi ini maka responden merasa menjadi lebih tenang dan nyaman. Menurut Purwanto dan Zulaikah (2009) dalam Solehati, \& Kosasih, (2015), dengan menyebut nama Allah berarti ingat kepada Allah, ingat ini tidak hanya sekedar menyebut nama Allah dalam lisan atau dalam pikiran dan hati, akan tetapi menyebut nama Allah yang dimaksud adalah ingat akan Zat, Sifat dan PerbuatanNya kemudian memasrahkan hidup dan mati kepada-Nya. Sikap pasrah yang mendasari menyebut nama Allah merupakan sikap pasif yang mutlak dibutuhkan dalam relaksasi.

Benson dan Proctor (2009) dalam Solehati, \& Kosasih, (2015) mengatakan selain mengurangi nyeri pasca bedah, Relaksasi Benson menghambat aktifitas saraf simpatik yang mengakibatkan penurunan terhadap konsumsi oksigen oleh tubuh dan selanjutnya otot-otot tubuhmenjadi relaks sehingga menimbulkan perasaan tenang 
dan nyaman. Selain itu, Relaksasi Benson berfokus pada kata atau kalimat tertentu yang diucapkan berulang kali dengan ritme teratur dan disertai sikap yang pasrah pada Tuhan Yang Maha Kuasa sesuai keyakinan pasien memiliki makna menenangkan. Responden yang melakukan terapi Benson dengan melafalkan dzikir, maka syaraf pusat dengan bekerja sesuai teori gate control, dimana aktivasi pusat otak yang tinggi dapat menyebabkan gerbang sumsum tulang menutup sehingga memodulasi dan mencegah input nyeri untuk masuk ke pusat otak yang lebih tinggi untuk dinterpretasikan sebagai pengalaman nyeri (Sitepu, 2009). Manfat dari terapi benson bukan saja sebagai penurun skala nyeri tetapi juga dapat membatu dalam kualitas tidur pasien. Penelitian Rambod, Mohammadi, Pasyar, \& Rafii, (2013) menjelaskan dengan pemberian terapi benson dapat meningkatkan kualitas tidur pasien hemodialisa di rumah sakit Teheran Iran.

\section{Simpulan}

Terdapat pengaruh terapi relaksasi Benson terhadap skala nyeri pada pasien post operasi Benigna Prostat Hiperplasia di Ruang Kenanga RSUD Dr. H Soewondo Kendal.

\section{REFERENSI}

Amalia , R. (2010). Faktor-Faktor Resiko Terjadinya Pembesaran Prostat Jinak (Studi Kasus di RS Dr Kariadi, RS Sultan Agung, RS Roemani Semarang). Prosiding Seminar Nasional (pp. 167-171). Semarang: LPPM UNIMUS Semarang. $\quad$ Retrieved from http://jurnal.unimus.ac.id

Datak, G., Yetti, K., \& Hariyati, R. T. (2008). Efektifitas Relaksasi Benson Terhadap Nyeri Pasca Bedah Pada Pasien Transurethral Resection Of The Prostat. Jurnal Keperawatan Indonesia, 12(3), 173-178. Retrieved from http://jki.ui.ac.id

Fitria, C. N., \& Ambarwati, R. D. (2015). Efektifitas Tehnik Relaksasi Progresif Terhadap Intensitas Nyeri Pasca Operasi Laparatomi. Jurnal Keperawatan GSH, 4, 1-8. Retrieved from

http://iournal.akpergshwng.ac.id/index.php/ gsh/article/view/10/8

Haynes, A. B., Weiser, T. G., Berry, W. R., Lipsitz, S. R., Breizat, A. H., Dellinger, E. P., ... Joseph, S. (2009, Januari 29). A Surgical Safety Checklist to Reduce Morbidity and Mortality in a Global Population. The New England Journal of Medicine, 491-499. doi:DOI: 10.1056/NEJMsa0810119

Kneale, J. D., \& Peter, S. D. (2011). Keperawatan Ortopedik dan Trauma. Jakarta: EGC.

Notoatmodjo, S. (2012). Metode Untuk Ilmu Kesehatan. Jakarta: Rineka Cipta.

Nursalam, \& Batticaca, F. B. (2009). Asuhan Keperawatan Pada Pasien Dengan Gangguan Sistem Perkemihan. Jakarta: Salemba Medika.

Potter, P. A., \& Perry, A. G. (2009). Buku Ajar Fundamental Keperawatan: Konsep, Proses dan Praktik. Jakarta: EGC.

Pranata, A. E., \& Prabowo, E. (2014). Asuhan Keperawatan Sistem Perkemihan Edisi 1 Buku Ajar. Yogyakarta: Nuha Medika.

Purnomo, B. B. (2011). Dasar-Dasar Urologi Edisi 3. Jakarta: Sagung Seto.

Rambod, M., Mohammadi, N. P., Pasyar, N., \& Rafii, F. (2013, Desember). The Effect of Benson's Relaxation Technique on the Quality of Sleep of Iranian Hemodialysis Patients: a Randomized Trial. Journal Elsivier, Volume 21(6), 577-584. doi:doi: 10.1016/j.ctim

Rasubala , G. F., Kumaat , L. T., \& Mulyadi . (2017, Februari). Pengaruh Tehnik Relaksasi Benson Terhadap Skala Nyeri Pada Pasien Post Operasi DI RSUP Prof Dr. R.D Kandou dan RS TK. III R.W Mongonsisi Teling Manado. eJournal Keperawatan (e-Kp), Volume 5(No 1). Retrieved

from https://media.neliti.com/media/publications /108176-ID-pengaruh-teknik-relaksasibenson-terhada.pdf

Samidah, i., \& Romadhon. (2015). Faktor-Faktor yang berhubungan Dengan Kejadian Benigna Prostat Hyperplasia (BPH) Di Poli Urologi RSUD Dr. M Yunus Bengkulu. Journal of Nursing and Public Health, Volume 3, No 1, 61-68. 
Sampekalo, Manoarfa, \& Salem. (2015). Angka kejadian yang disebabkan oleh BPH di RSUD Prof. Dr. R.D Kandu Manado. Jurnal e-Clinic (eCl), 568-572.

Setyawan, B., Saleh, I., \& Arfan, I. (2016). Hubungan Gaya Hidup Dengan Kejadian Benigna Prostat Hyperplasia (Studi Di RSUD Dr. Soedarso Pontianak). LPPI Universitas Muhammadiyah Pontianak, 1-19. Retrieved from http://repository.unmuhpnk.ac.id/166/1/jur nal.pdf

Sitepu, N. F. (2009). Effect of Zikir Meditation on Post Operative Pain Among Muslim Patients Undergoing Abdominal Surgery, Medan, Indonesia. Prince of Songkla University. Retrieved from http://kb.psu.ac.th/psukb/bitstream/2010/5 953/1/313829.pdf

Solehati,, T., \& Kosasih, C. E. (2015). Konsep \& Aplikasi Relaksasi dalam Keperawatan Maternitas. Bandung: Refika Aditama.

Sukesih, \& Ros, E. M. (2017). Pengaruh Afirmasi Positif terhadap Penurunan Nyeri Pada Pasien Post Operasi BPH Di RSUD RAA Soewondo
Pati. Indonesia Jurnal Perawat, Vol 2, 30-34. Retrieved from http://ejr.stikesmuhkudus.ac.id/index.php/ij $\mathrm{p} /$ article/download/265/186

Sunaryo, T., \& Lestari , S. (2015, November). Pengaruh Relaksasi Benson Terhadap Penurunan Skala Nyeri Dada Kiri Pada Pasien Acute Myocardial Infarc DI RS Dr Moewardi Surakarta . Jurnal Terpadu Ilmu Kesehatan, Volume 4, No 2, 82-196. Retrieved from http://jurnal.poltekkessolo.ac.id/index.php/Int/article/viewFile/138 $\angle 128$

Wijaya, S. A., \& Putra, M. Y. (2013). Keperawatan Medikal Bedah: Keperawatan Dewasa, Teori Contoh Askep. Yogyakarta: Nuha Medika.

Wulandari, A., \& Asnindari, L. N. (2018). Pengaruh Mobilisasi Dini Terhadap Nyeri Post Operasi TURP Pada Pasien BPH Di RSU PKU Muhammadiyah Bantul. Jurnal Kebidanan dan Keperawatan Aisyiyah Universitas Aisyiyah Yogyakarta, 1-13. Retrieved from http://digilib.unisayogya.ac.id/3929/1/NASP $\underline{\text { UB\%20BU\%20ANI-1.pdf }}$ 